Saeculum Christianum

vol. XXIII (2016)

pp. $214-227$

MARTA WIRASZKA

HIS UKSW, Warszawa

\title{
ANTONI MESSING - CO-CREATOR OF THE BLESSED VIRGIN MARY'S STATUE LOCATED IN FRONT OF THE REFORMED CHURCH AND CO-AUTHOR OF A SERIES OF TOMBSTONES PATTERNED AFTER IT AND RAISED AT THE CEMETERIES OF WARSAW
}

In the first half of the nineteenth century stone-masonry and statuary workshops began to appear in the suburbs of Warsaw in the neighbourhood of four cemeteries established at the turn of the eighteenth and the nineteenth century: Świętokrzyski cemetery, Powązkowski cemetery and two evangelical cemeteries located in Wola district. The workshops belonging to Jan Józef Mantzel (1806-1875) located at the address: ul. Chłodna 191', Jan Ścisłowski (approx. 1805-1847) located at the address: ul. Powązkowska $6^{2}$ and Aleksander Sikorkski (approx. 1822-1881) located at the address: ul. Wolska $14 / 16^{3}$ enjoyed great renown and were highly sought after. In these workshops both the tombstones adorning Warsaw cemeteries and the tombstones exported abroad were made 4 .

\footnotetext{
1 The stonemason and statuary workshop was opened in 1841 at the address: ul. Chłodna 19 (mortgage no. 927B) by Jan Józef Mantzel (1806-1875), a sculptor and the owner of the stonemason workshop located at Leszno Street (mortgage no. 735, mortgage no. 733 from 1823) established by his father, Józef Jan (approx. 1772-1846). In 1868 Mantzel transferred ownership of the workshop to his son, Józef Jan (1834-1904). Later the workshop was operated by Władysław Tuszyński. M.I. Kwiatkowska, Józef Jan Mantzel-warszawski rzeźbiarz i przedsiębiorca, „Rocznik Warszawski", 1996, no. 26, pp. 47-76; idem, Rzeźbiarze warszawscy XIX wieku, Warszawa 1995, p. 9, pp. 58-59, pp. 196-201; idem, Józef Jan Mantzel (approx. 1772-1846), in: Słownik artystów polskich i obcych w Polsce działajacych (zmarłych przed 1966 r): malarze, rzeźbiarze, graficy, editor J. Derwojed, vol. 5, Warszawa 1993, p. 333; idem, Józef Jan Mantzel (1834-1904), in: Słownik artystów polskich i obcych w Polsce działajacych (zmartych przed 1966 r): malarze, rzeźbiarze, graficy, vol. 5, editor J. Derwojed, Warszawa 1993, pp. 333-335; Z. Bieniecki, Dom własny rzé́biarza warszawskiego Jana Józefa Mantzla, „Rocznik Warszawski”, 1972, no. 11, pp. $173-204$.

2 The stonemason workshop at the address: ul. Powązkowska 6 (mortgage no. 27C) had been located there since February 1834. It was initially owned by Jan Ścisłowski who previously operated a workshop at the same street but on the left side of the road, looking towards Warsaw. After his death it was taken over by Antoni Messing, later by Jan Sikorski and after Sikorski's death - by his son-in-law, Józef Todtleben. „Kurier Warszawski”, 1834, no. 47, p. 242; Skorowidz mieszkańców miasta Warszawy z przedmieściami na rok 1854 ułożony pod kierunkiem Zarządu Policji, Warszawa 1854, p. 206; Księga adresowa przemystu fabrycznego w Królestwie Polskim na rok 1906, Warszawa 1905, advertisment no. 1186.

3 The stonemason and statuary workshop located at the address: ul.Wolska 14/16 (mortgage no. 3077) was established around 1850 by Aleksander Sikorski. In 1879 it was moved to the address: ul. Srebrna 10 (mortgage no. 5062). In 1884 Sikorski's inheritors sold the plot along with buildings to „Józef Norblin \& Wiktor Herteux” Stonemason Company. Soon after Jan Lilpop joined the company. He replaced Norblin who founded his own company at the address: ul. Dzika 71. B. Rogalska, Pałacyk przy Srebrnej, „Almanach Muzealny”, 1/1997, pp. 117-119; M.I. Kwiatkowska, Rzeźbiarze..., p. 163; T.W. Świątek, Rody starej Warszawy, Warszawa 2000, pp. 142-146.

4 See: M.I. Kwiatkowska, Rzeźbiarze..., pp. 58-59, p. 59, p. 105. Ibidem
} 
In the house owned by Jan Ścisłowski (mortgage no. 27C), where a stonemason's workshop was located, Antoni Messing, a sculptor and son of Jan Messing and Urszula née Sikorska, born in 1821 in Krotoszyn poviat town in the Grand Duchy of Posen, lived and worked ${ }^{5}$. Most probably Messing arrived in Warsaw in the Thirties of the nineteenth century. In 1847 he took over management of the stonemason workshop ${ }^{6}$ which became his property in February 1851 after his marriage with Joanna (1834-1894), ${ }^{7}$ the daughter of the deceased Jana Ścisłowski. During the period of his ownership the workshop employed Szczepan Hein, a journeyman sculptor ${ }^{8}$. He also cooperated with other sculptors: Ludwik Kaufmann (1801-1855) and Tadeusz Czajkowski (1834-1867). Due to health reasons Messing was forced to forsake the well developing professional career at the age of 45 . He died on the 1st of November 1867 after a year-long fight against a serious disease ${ }^{9}$. He was buried in the family tomb in Powązki cemetery (plot no. 19, row 5), the same where the body of Jan Ścisłowski was laid to rest. After his death the workshop was taken over by Jan Sikorski (1832-1906), married to Teofila Ścisłowska (1842-1900), the daughter of Jan Ścisłowski and Maria née Messing ${ }^{10}$.

Advantageous location of the workshop, almost directly opposite the gate of Powązkowski cemetery, a large selection which could satisfy all demands, affordable prices and particularly diligent performance of work, which distinguishes this manufacturer, as noticed in 1859 by an anonymous author of a recommendation posted in "Kurier Warszawski [Warsaw Courier]" , resulted in Messing enjoying a significant amount of orders. The lack of signatures made it possible to connect barely three tombstones with the name of the sculptor, mainly on the basis of information contained in press. Two of them are located on Powązki cemetery: tombstones of a poet Antoni Malczewski (plot no. 14, row 3; 1854) and a medicine practitioner Teofil Lesiński (plot no. 179, row 3; 1861-1862); the third one, commemorating an iron goods manufacturer Fryderyk Krzysztof Brun, is located on the Evangelical-Augsburg cemetery at Młynarska Street in Warsaw (lane no. 24, no. 3/5; approx. 1867) ${ }^{12}$.

The works of Messing in the field of religious sculptures are equally scarce. In his workshop only three stone statues of Madonna set on decorative pedestals were sculpted and later placed in front of Warsaw churches: the Observant Fathers Church at Senatorska Street (1851), the Carmelites Church at Leszno Street (1859) and the Paulists Church at Długa Street $(1863)^{13}$. The first of the statues was based on the model created by Ludwik Kaufmann and the remaining two were made by Tadeusz Czajkowski. On the pedestal of the statue located on the courtyard of the Observant Fathers Church the signature of the sculptor was placed: A. MESSING fecit. It is the sole work signed by this artist.

\footnotetext{
Material posted on www.szukajwarchiwach.pl website [accessed on: 15.03.2016].

6 According to M.I. Kwiatkowska and A. Melbechowska-Luty the workshop was taken over by Messing as early as in 1841 . This information was not confirmed by archival materials. M.I. Kwiatkowska, A. Melbechowska-Luty, Antoni Messing (ok. 1822-1867), in: Słownik artystów polskich i obcych w Polsce działajacych (zmartych przed 1966 r): malarze, rzeźbiarze, graficy, vol. 5, editor J. Derwojed, Warszawa 1993, p. 495; M.I. Kwiatkowska, Rzeźbiarze..., p. 59.

Archiwum..., Akt matżeństwa nr 32/ 1851.

8 Skorowidz mieszkańców..., p. 106.

9 „Kurier Warszawski”, 1867, no. 245, p. 1548.

10 W. Dzierżanowski, Przewodnik warszawski informacyjno-adresowy na rok 1869, Warszawa 1869, p. 366.

11 „Kurier Warszawski”, 1859, no. 238, p. 1291.

12 Quoting: M.I. Kwiatkowska, A. Melbechowska-Luty, Op. Cit., p. 495. Ibidem

13 Ibidem.
} 
Apart from the orders for sculptures, Messing also took orders for stonemason works on the Warsaw buildings contemporarily under construction, including fitting-out works in the tenement house of baron Stanisław Lesser at the address ul. Miodowa 21/23 (mortgage no. 490/491), which was built according to designs and under direction of Jerzy Völck in the years $1850-1851^{14}$.

Until now the scant knowledge of works with confirmed authorship has not enabled researchers to closely examine the works of Antoni Messing. Apart from the short biographic entry written by Maria Irena Kwiatkowska and Aleksandra Melbechowska-Luty, which was included in Stownik artystów polskich i obcych..., the name of Messing is only occasionally recorded in connection with one of his rare works ${ }^{15}$. Among those one drew particular attention of critics reflected by the nineteenth century Warsaw press. This work was the statue of the Immaculately Conceived Blessed Virgin Mary erected in front of the St. Anthony Church, on the courtyard flanked on two sides with deambulatorio and separated from Senatorska Street with metal bars ${ }^{16}$.

The statue was financed with devout contributions and owing to efforts of Fr. Józef Czapski, the former Guardian of this monastery, in cooperation with Fr. Ludwik Piętka, vicesyndic of the congregation of Warsaw Observant Fathers. The statue was solemnly consecrated on Sunday on the 7th of December 1851. The consecration was complemented by Fr. Paweł Stopiński in the assist of congregation of Observant Fathers and in presence of numerous faithful ${ }^{17}$. Towards the end of July 1853 the statue was illuminated with two cast iron lanterns created in the Warsaw factory of Karol Minter, which were placed in the front and to the $\operatorname{sides}^{18}$. Due to the use of non-translucent glass in the lanterns' canopies the light was focused solely on the statue of Madonna which, as it was emphasised by the press, resulted in the statue of the Mother of God appearing to be surrounded with heavenly lights during the evening hours ${ }^{19}$. The idea to illuminate the statue was adopted by monks due to numerous contributions sent with the intention to achieve this goal. In the beginning

\footnotetext{
14 „Kurier Warszawski”, 1850, no. 290, p. 1548; „Kurier Warszawski”, 1851, no. 284, p. 1490. Tomasz Grygiel wrote extensively on the subject of baron Lesser's house at Miodowa Street. The author does not mention the name of Antoni Messing in the text or in annotations. T. Grygiel, Dom Lesserów w Warszawie - nieznane dzieło ,stylu maksymiliańskiego, in: Architektura XIX i początku XX wieku, editor - idem, Wrocław-Warszawa-Kraków 1991, pp. 39-53.

15 M.I. Kwiatkowska, A. Melbechowska-Luty, Op. Cit., p. 495. See also: J. Bartoszewicz, Kościoty warszawskie rzymsko-katolickie opisane pod względem historycznym, Warszawa 1855, p. 275; F.M. Sobieszczański, Kościót oo. Reformatów w Warszawie, „Tygodnik Ilustrowany”, 8/1863, no. 208, pp. 364-365; W. Gomulicki, I. Szmideberg, Ilustrowany przewodnik po Warszawie, Warszawa 1880, p. 96; Ilustrowany przewodnik po Warszawie wraz z treściwym opisem okolic miasta, Warszawa 1893, p. 72; F.M. Sobieszczański, Warszawa. Wybór publikacji, vol. 2, Warszawa 1967, pp. 164-165.

16 „Kurier Warszawski”, 1851, no. 326, pp. 1739-1740; Pomniki święte w Warszawie, „Kalendarz Warszawski Popularno-Naukowy J. Ungra", 1855, pp. 62-63. The statue of the Blessed Virgin Mary was damaged during the Warsaw Uprising. Owing to the efforts of Antoni Kitliński, the first parson of this parish after the war, it was restored. The missing head was sculpted by Jan Ślusarczyk, a graduate of the Academy of Fine Arts in Warsaw. A.J. Szteinke, Kościót Świętego Antoniego i klasztor franciszkanów-reformatów w Warszawie 1623-1987, Kraków 1990, pp. 92-93, p. 116.

17 „Kurier Warszawski”, 1851, no. 326, pp. 1739. The time of erection is also stated on the pedestal, engraved on the side facing the monastery: "1851 / Financed / from devout / contributions".

18 At that time the statue was restored through funding provided by Salwian Jakubowski, a citizen of Warsaw. „Kurier Warszawski”, 1853, no. 196, p. 965; „Kurier Warszawski”, 1853, no. 204, p. 1005.

19 Statua Matki Boskiej przed kościołem św. Antoniego w Warszawie, „Kłosy”, 20/1875, no. 500, p. 55.
} 
of September 1852, the superior of the monastery, Fr. Andrzej Łęgowski, appealed through press to the aforementioned master builders and artists to present a proposal for the type and arrangement of lamps or lanterns to ensure continuous illumination of the statue ${ }^{20}$. Józefa Watke, whose husband operated a private boarding school for boys opposite the monastery, agreed to bear the costs ${ }^{21}$.

The idea of illuminating statues of God and saints, initiated by Observant Fathers, rapidly spread across the capital ${ }^{22}$. Soon it was used for illuminating the statues of: Blessed Virgin Mary and Saints Felix and John Nepomucene located in front of the Capuchin Friars Church $(1855)^{23}$, the statue of Christ in front of the Holy Cross Church at Krakowskie Przedmieście Street $(1859)^{24}$, the statue of Blessed Virgin Mary in front of the Carmelites Church at Leszno Street $(1860)^{25}$ and the statue of Mother of God set above the pediment of the main entrance to "Pod Karczochem [Under the Artichoke]" Palace at the address: Aleje Ujazdowskie 14 $(1856)^{26}$. The last of the listed statues was made in the same style and line as the one in front of the XX. Observant Fathers Church ${ }^{27}$. Thus it is possible that this sculpture, no longer existing, could have been made in the workshop of Antoni Messing.

Outside of Warsaw a similar construct was used at that time to illuminate the painting of Mother of God (1854/1855) placed on the external facade near the top of the chapel where the miraculous painting of the Mother of God is located. Those orders were accomplished by Karol Minter's factory ${ }^{28}$. In approx. 1887 the lanterns standing by the tomb of the family of Melchior Nestorowicz on the Warsaw Powązki cemetery (plot no. 32, row 2), modelled after the designs popularised by this factory, were created [pic. 1] ${ }^{29}$. They were illuminating the figure of Lady Mary of the Rosary set on a high, rectangular pedestal. The form of these

20 „Kurier Warszawski”, 1852, no. 231, p. 1215.

21 A.J. Szteinke, Op. Cit., p. 93.

22 One of the first researchers who drew attention to this fact was Juliusz Bartoszewicz. J. Bartoszewicz, Op. Cit., p. 275. See also: F.M. Sobieszczański, Kościól..., p. 365; idem, Warszawa ..., p. 165.

23 The lanterns were produced in Karol Minter's factory. „Kurier Warszawski”, 1855, no. 346, p. 1765; „Kalendarz Warszawski Popularno-Naukowy J. Ungra”, 1856, pp. 109-111.

24 „Kurier Warszawski”, 1859, no. 46, p. 233.

25 The lanterns were produced in „Evans, Lilpop et Comp.” factory. „Kurier Warszawski”, 1860, no. 146, p. 814.

26 „Kurier Warszawski”, 1856, no. 215, p. 1110. The property designated with mortgage no. 1726 C was purchased on the 12th of April 1844 by Jan Kanty Sokołowski, counsellor of the court and commissioner of the Kujawskie province. In 1845 the buildings and installations located on the parcel were redeveloped according to the designs of an architect Antoni Corrazzio. From the side of Aleje Ujzadowskie a Neogothic palace-villa was built, a part of which consisted of an eighteenth century octagonal rotunda called "Karczoch [The Artichoke]" due to the shape of its top. After the death of Sokołowski in 1855 his daughter, Michalina Mokrzycka, sold the estate to Mamert Pawluć (31st of August 1855). A year later a statue of Madonna was set above the pediment of the entrance and illuminated with a decorative lamp. See: J. Roguska, Warszawski pałacyk „,Pod Karczochem” świadectwem trzech epok?, „Kwartalnik Architektury i Urbanistyki”, 1982, issue 1-2, pp. 109-127.

27 „Kurier Warszawski” 1856, no. 215, p. 1110.

28 For this reason in the fall of 1854 Karol Minter, at that time travelling to Munich, stopped in Jasna Góra Monastery to take necessary measurements. „Kurier Warszawski”, 1854, no. 267, p. 1364.

29 The Metal and Lacquered Goods Factory of Karol Minter (established in 1828) already did not exist at that time. In 1881 it was transformed into the Warsaw Metal Goods Factory "Wulkan [Volcano]" Joint Stock Company which produced pewter and enameled dishes only. Thus the lanterns located on the tomb of Melchior Nestorowicz must have been manufactured in a different workshop but they were based on the designs developed by Minter's company. M. Dubrowska, Rzemiosło artystyczne Minterów: 1828-1881, Warszawa 1987, pp. 63-64. Obituaries: „Kurier Warszawski”, 1885, no. 343a, p. 3; „Kurier Warszawski”, 1886, no. 389a, p. 3. 


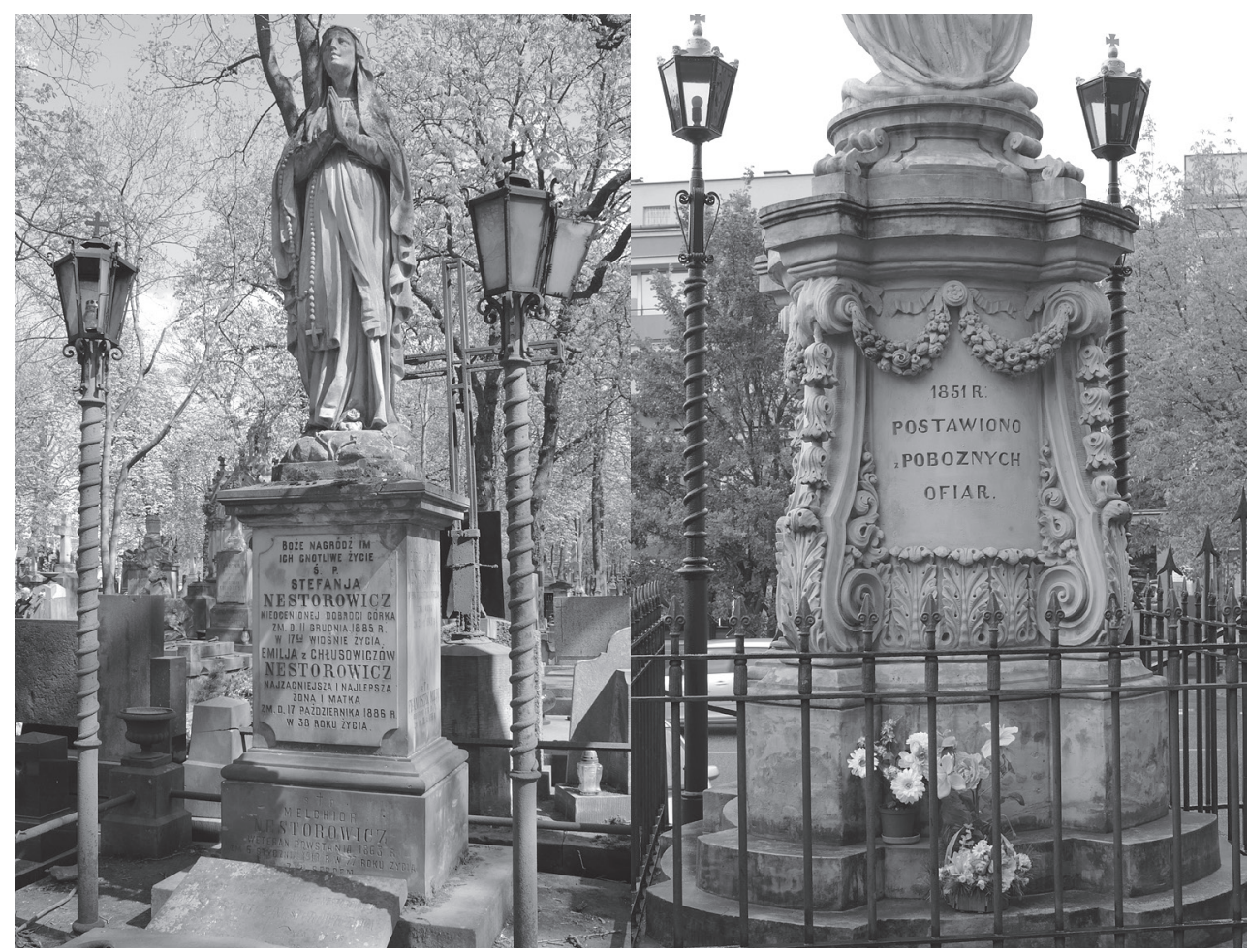

The tombstone of the Nestorowicz family in Powązki cemetery in Warsaw, approx. 1887. The Photo by M. Wiraszka
The pedestal of the Immaculately Conceived Blessed Virgin Mary in front of the Observant Fathers Church in Warsaw, 1851. The Photo by M. Wiraszka

lanterns is identical to those erected more than 30 years prior in front of the Observant Fathers and the Capuchins Churches, and which were confirmed to be made in Minter's workshop.

The similarities to the statue made by Messing are not restricted solely to the manner and form of illumination of the statue. Inventorying conducted in Warsaw cemeteries allowed us to discover and isolate a group of tombstone faithfully reproducing the shape and decorative elements of the pedestal of the Blessed Virgin Mary statue [pic. 2]. This group, consisting of 8 examples, was created between 1853 and 1864. The majority of these tombstones are located on Powązkowski cemetery with the exception of a single one standing on EvangelicalAugsburg cemetery. All represent the same type of a tombstone in the form of a cross set on a decorative pedestal. This pedestal, in the style of late Baroque, has the shape of a cylinder, slightly narrowing towards the top, set on a wider, three-step base and topped with a fineprofile cornice. Its shaft is adorned with four corner volutes with ends coiling towards the inner side at the bottom and coiling outwards at the top. The volutes are supported by fitted parts of the cornice and the base, which form rectangular protuberances along the volutes' axes. The spines of corbels are decorated with campanula forming overhangs reaching twothirds of the height of the pedestal. Protuberances on the bottom of the volutes are decorated 
with acanthus leaves also adorning the base of the pedestal. The upper adornments consist of two flower garlands spreading between the volutes and tied with a ribbon to decorative pegs set in the middle of each side. The space between corbels and decorative elements was used for putting down inscriptions.

The series of tombstones, which directly mimic the form and the ornamentation of the pedestal signed by Messing, opens with the tombstone of Andrzej Wołowski (departed on the 16th of August 1852) - a governor of Treasury Committee, erected in approx. 1853 in Powązkowski cemetery by the sister of the departed, Teresa Wołkowska née Szymanowska (plot no. 14, row 5). Funeral services in memory of the dearly departed Andrzej Wołkowski took place on the 25th of August 1852 in the St. Anthony Church at Senatorska Street. The following anniversary services also took place there ${ }^{30}$. Connecting these facts with the form of Wołowski's tombstone inclines us to draw the conclusion that the funder knew Messing's work in person and decided to reproduce the decorative pedestal and instead of the statue of Blessed Virgin Mary she decided to place a cross on it, less expensive to make and more expressive in the Christian-Cemetery symbolism. Beams of the cross, profiled and with octagonal cross-section, consisting of alternately arranged rolls and congees, were decorated with floral relief at the base and the termination of cross' arms. The point where the beams intersect was accentuated with a medallion depicting three-dimensional head of Christ in a crown of thorns [pic. 3].

The following orders to reproduce this model were accomplished in Powązkowski cemetery $^{31}$. In the chronological order these were the tombstones of: Elżbieta Colin (1853, plot no. 24, row 6) ${ }^{32}$, Marcjanna Dafonow née Obrąpalska (1854, plot no. 159, row 4) ${ }^{33}$, Aleksander Lepigé (1854, plot no. 24, row 1) ${ }^{34}$, Aniela Łubieńska née Kamieńska (1857,

30 Obituaries: „Kurier Warszawski”, 1852, no. 219, p. 1155; „,Kurier Warszawski”, 1852, no. 223, p. 1175; „Kurier Warszawski”, 1853, no. 211, p. 1037; „Kurier Warszawski”, 1854, no. 211, p. 1107; „Kurier Warszawski”, 1855 , no. 213, pp. 1094-1095.

31 The tombstones were dated on the basis of the information contained in the obituaries posted in "Kurier Warszawski" and concerning transfer of the body of the deceased to the family grave and consecration of the tombstone. If such information on the creation of tombstones were unavailable an approximate date of creation was assumed according to the most frequent funerary practice - one year from the date of death of the departed. See: A.T. Tyszka, Nekrologi „Kuriera Warszawskiego” 1821-1939, vol. 2, 1846-1852, Warszawa 2004; idem, Nekrologi „,Kuriera Warszawskiego” 1821-1939, vol. 3, 1853-1858, Warszawa 2007; idem, Nekrologi „, Kuriera Warszawskiego” 18211939, vol. 4, 1859-1861, Warszawa 2012.

32 Obituaries: „Kurier Warszawski”, 1852, no. 310, p. 1620-1621; „Kurier Warszawski”, 1852, no. 320, p. 1672; „Kurier Warszawski”, 1853, no. 322, p. 1589. Biographical data: Taryfa domów miasta Warszawy i Pragi z planem ogólnym i 128 szczegółowych planików ulic i domów - ułożone przez inż. m. Warszawy H. Świątkowskiego, Warszawa 1852 , p. 54

33 Obituaries: „Kurier Warszawski”, 1853, no. 304, p. 1497; „Kurier Warszawski”, 1854, no. 6, p. 30; „Kurier Warszawski”, 1854, no. 123, p. 651; „Kurier Warszawski”, 1854, no. 300, p. 1521. Dating the tombstone was possible due to the information concerning funeral services which, unlike other major annual services, were celebrated in the church located in Powązki cemetery. According to the contemporary practices, the transfer of the remains and consecration of the headstone took place directly after the funerary service in the St. Charles Borromeo Church located in Powązki cemetery.

34 Obituaries: „Kurier Warszawski”, 1853, no. 152, p. 773; „Kurier Warszawski”, 1853, no. 225, p. 1109. The date of the raising of the tombstone was determined on the grounds of an inscription on the base: "FOR ALEKSANDER/ LEPIGÈ/ BEST HUSBAND/ A WIFE FULL OF SORROW/ ZOFIA Née PIEŃKOWSKA/ ERECTED THIS TOMBSTONE/ 1854". The annotation in the obituary informing of the fact that: Tomorrow [30 VIII 1853], in the Powazki Church a service will be celebrated in memory of the dearly departed Aleksander Lepigè; after conclusion of the services the remains of the departed will be transferred from the storage to the family tomb should not be equated with the information concerning raising the tombstone over the grave. It is more probable 
plot no. 158, row 5) ${ }^{35}$, Hortensja Wiktoria Szpadkowska née Bernatowicz (1857, plot no. 29, row 4$)^{36}$ and Antoni Ciesielski (approx. 1858, plot no. 20, row 3) ${ }^{37}$. The list concludes with the tombstone commemorating Fryderyk Karol Moes (1808-1863) - an industrialist, owner of a cotton spinning plant in Łódź, wool factories in Zgierz and a tapestries manufacturing plant in Warsaw ${ }^{38}$, erected in 1864 in Evangelical-Augsburg cemetery (lane no. 56, no. 5). All the listed tombstones retained the same architectural form and sculpture details. The differences between them result from adopting different proportions and the current preservation state ${ }^{39}$. Only the tombstone of Antoni Ciesielski deviates from the template with a slightly different structure of the pedestal. Instead of arching convex surfaces it has four concave sides with corner volute corbels with individual garlands of laurel attached at the top.

Apart from the eight examples most certainly resembling the works of Messing, a second group of objects exists representing a similar type of a tombstone in the form of a cross set on an ornamental pedestal which is a simplified form of the previously described design. The examples from this group are characterised by an identical architectural structure of the pedestal with the exception of lacking decorative reliefs. Since the oldest tombstones of this type were erected in 1855, one in Powązki cemetery for Franciszek Reych, a judge of the Tribunal of Commerce and a wine and spices merchant (plot no. 11 row 1$)^{40}$ [pic. 4] and the other in Russian Orthodox cemetery in Wola to commemorate Aleksander Pogonjałow ${ }^{41}$, a primate and the chief chaplain of General Military Army who died in 1855, it should be assumed that these tombstones were in terms of chronology the second variant of the first design.

that the tombstone was raised not three months but a year after the death of the departed. Biographical data: Archiwum Państwowe m.st. Warszawy, Akta stanu cywilnego parafii rzymskokatolickiej św. Aleksandra w Warszawie, certificate of death no. 302/1853. Published on the www.szukajwarchiwach.pl website [accessed on: 15.03.2016]; E. Szulc, Cmentarz ewangelicko-augsburski w Warszawie. Zmarli i ich rodziny, Warszawa 1989, p. 323-324.

35 Obituaries: „Kurier Warszawski”, 1856, no. 121, pp. 619-620; „Kurier Warszawski”, 1856, no. 127, pp. 655656 ; „Kurier Warszawski”, 1857, no. 119, p. 630. The date of creation can also be found on the base of the tombstone.

36 Obituaries: „Kurier Warszawski”, 1857, no. 207, p. 1125. Biographical data: Archiwum Państwowe m.st. Warszawy, Akta stanu cywilnego parafii rzymskokatolickiej św. Krzyża w Warszawie, certificate of death no. 1799/ 1856. Published on the www.szukajwarchiwach.pl [accessed on 15.03.2016]; S. Loza, Architekci i budowniczowie w Polsce, Warszawa 1954, p. 300.

37 Obituaries: „Kurier Warszawski”, 1857, no. 257, p. 1386; „Kurier Warszawski”, 1858, no. 247, p. 1321.

38 Obituaries: „Kurier Warszawski”, 1863, no. 204, p. 1009; „Kurier Warszawski”, 1864, no. 247, p. 1417. Biographical data: „Kurier Warszawski”, 1848, no. 179, p. 858; „Kurier Warszawski”, 1852, no. 173, p. 915; „Kurier Warszawski”, 1854, no. 208, p. 1094; „Kurier Warszawski”, 1859, no. 171, p. 4; E. Szulc, Op. Cit., pp. $394-395$.

39 Crosses were not preserved on the tombstones of Aniela Łubieńska and Hortensja Szpadkowska. On the tombstones of Marcjanna Safonow and Aleksander Lepigè the intersection of the cross arms was accentuated with a three-dimensional head of Madonna and a relief rosette, respectively.

40 Funeral services after the death of the departed were held in the Observant Fathers Church. Obituaries: „Kurier Warszawski”, 1855, no. 65, p. 313; „Kurier Warszawski”, 1855, no. 70, p. 334; „Kurier Warszawski”, 1855 , no. 280, p. 1422. Biographical data: „Kurier Warszawski”, 1834, no. 249, p. 1376; „Kurier Warszawski”, 1852, no. 283, p. 1482; Archiwum Państwowe m.st. Warszawy, Akta stanu cywilnego parafii rzymskokatolickiej św. Andrzeja $w$ Warszawie, certificate of death no. 153/1855. Published on the www.szukajwarchiwach.pl [accessed on 15.03.2016]; Taryfa domów..., p. 15.

41 Obituaries: „Kurier Warszawski”, 1855, no. 18, p. 85. 


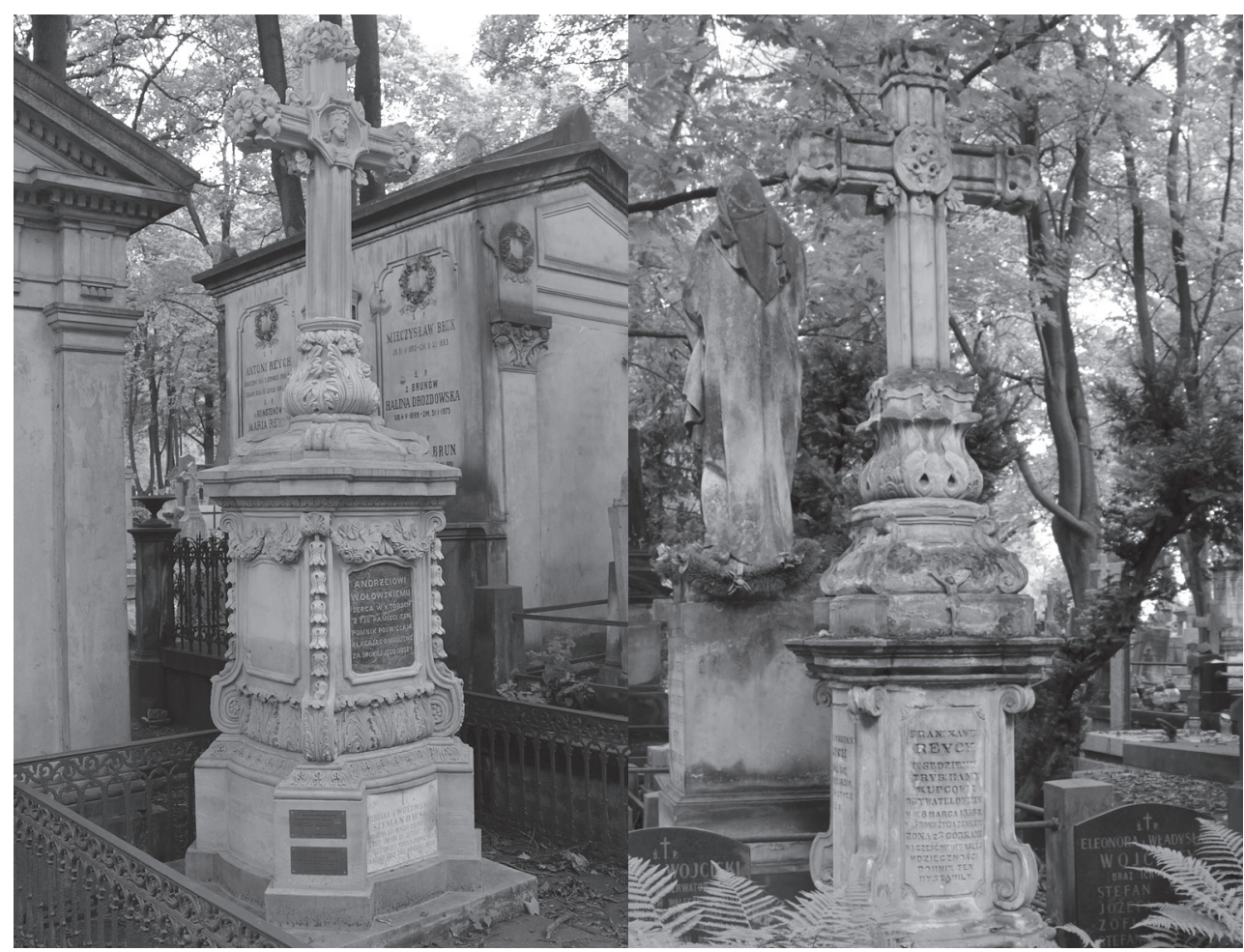

The tombstone of Andrzej Wołowski in Powązki cemetery in Warsaw, approx. 1853. The Photo by M. Wiraszka
The tombstone of Franciszek Reych in Powązki cemetery in Warsaw, 1855. The Photo by

M. Wiraszka

In Powązkowski cemetery identical tombstones were raised on the graves of: Julianna and Eliasz Kelch, a married couple (approx. 1856, plot no. 33, row 3) ${ }^{42}$, Tomasz Trylski $\left(1856 \text {, plot no. 16, row 4) }{ }^{43} \text {, Wincenty Temporowski (approx. 1858, plot no. 157, row } 2\right)^{44}$ and Mikołaj Jarmoszyński (approx. 1862, plot no. 157, row 3) ${ }^{45}$. Additional three tombstones were erected in Evangelical-Augsburg cemetery for Ludwik Antoni Salinger (approx.

42 Obituaries: „Kurier Warszawski”, 1853, no. 38, p. 202; „Kurier Warszawski”, 1855, no. 325, p. 1649. Biographical data: „Kurier Warszawski”, 1830, no. 339, p. 1760; „Przewodnik Warszawski”, 1/1826, p. 10; „Przewodnik Warszawski”, 2/1827, p. 11; „Przewodnik Warszawski”, 3/1829, p. 11; Skorowidz mieszkańców..., p. 139.

43 Obituaries: „Kurier Warszawski”, 1855, no. 202, p. 1038; „Kurier Warszawski”, 1855, no. 229, p. 1179; „Kurier Warszawski”, 1856, no. 199, p. 1030. Biographical data: „Przewodnik Warszawski”, 1/1826, p. 101; „Kurier Warszawski", 1837, no. 184, p. 2; Archiwum Państwowe m.st. Warszawy, Akta stanu cywilnego parafii rzymskokatolickiej św. Krzyża w Warszawie, certificate of death no. 2594/1855. Published on the www.szukajwarchiwach.pl [accessed on 15.03.2016].

44 Obituaries: „Kurier Warszawski”, 1858, no. 81, p. 413. Biographical data: „Korespondent Warszawski”, 1831, no. 38, p. 99; „Kurier Warszawski”, 1852, no. 3, pp. 9-10; Skorowidz mieszkańców..., p. 338.

45 Obituaries: „Kurier Warszawski”, 1862, no. 13, p. 68; „Kurier Warszawski”, 1862, no. 47, p. 253. Biographical data: Skorowidz mieszkańców..., p. 118. 
1857, plot no. I, opposite the lapidarium) ${ }^{46}$, Krzysztof Fryderyk Brun (approx. 1867, lane no. 24, no. 3/5) 47 and Ludwik Bogumił Reineke (approx. 1874, opposite the lanes no. 66 and 65$)^{48}$. Furthermore, in Evangelical Reformed cemetery a tombstone had been erected commemorating the departed members of the family of Jan Samuel Elsner, an apothecary (plot no. A, row 2) ${ }^{49}$. The tombstone was probably created between 1863 and 1867. At that time two of his young children had died: his son Stanisław, 10 years old (16th of October 1862) and his daughter Klementyna, 5 and a half years old (10th of January 1867) ${ }^{50}$. The form of commemoration was influenced by familial relations. The wife of Elsner, Julianna Teofila, was a daughter of Krzysztof Fryderyk Brun ${ }^{51}$. Therefore on the graves of related families identical tombstones were erected in the analogous period. Outside of Warsaw a tombstone of colonel Dellingzhauzen is located, erected in the cemetery in Bielsk Podlaski at Wojska Polskiego Street ${ }^{52}$.

According to the information posted in "Kurier Warszawski" the tombstone of Brun was made by Antoni Messing ${ }^{53}$. It should be, however, assumed that it was not made directly by him but only in his workshop. The deteriorating health limited the capability of the sculptor to work or even made working impossible in the last year before his death. In the context of the alleged authorship of the group of tombstones patterned after the Warsaw statue of Blessed Virgin Mary, the name of the sculpture emerges for the second time ${ }^{54}$ but it is the first time when attribution of work is directly confirmed. Taking into account that the majority of orders, with the exception of the tombstone of Ludwik Reinke (departed on the 15 th of December 1873), were accomplished in the years 1853-1867, it should be assumed that they were works of a single sculptor or, at least, were created in the same workshop. The conjecture that Messing was the creator of a series of similar tombstones does not raise major objections but the answer to the question: Did Messing also design them? is not as clear and requires further analyses.

The studies of Maria I. Kwiatkowska proved that the figure of Madonna commonly attributed to the sculptor was in reality the work of Ludwik Kaufman whereas Messing was

\footnotetext{
46 Obituaries: „Kurier Warszawski”, 1857, no. 5, p. 21; „Gazeta Warszawska”, 1857, no. 42, p. 6. Biographical data: K. Reychman, Szkice genealogiczne, Warszawa 1936, p. 183, p. 185.

47 Obituaries: „Kurier Warszawski”, 1866, no. 274, p. 1609; „Kurier Warszawski”, 1869, no. 12, p. 4. Biographical data: Taryfa domów..., p. 10; „Kurier Warszawski”, 1853, no. 336, p. 1687; E. Szulc, Op. Cit., pp. 67-68; T.W. Świątek, Op. Cit., pp. 9-20.

48 Obituaries: „Kurier Warszawski”, 1873, no. 250, p. 3.

49 J. i E. Szulcowie, Cmentarz ewangelicko-reformowany $w$ Warszawie. Zmarli i ich rodziny, Warszawa 1989, p. 67 .

50 Obituaries: „Kurier Warszawski”, 1862, no. 238, p. 1371; „Kurier Warszawski”, 1867, no. 9, p. 45.

51 „Kurier Warszawski”, 1898, no. 77, p. 4.

52 Further search carried out on cemeteries located outside Warsaw can increase the number of examples. Regarding the tombstone of colonel Dellingzhauzen - apart from discovering a low-quality picture an attempt at uncovering any more specific data concerning the departed resulted in failure. Dwieście lat bielskiej nekropolii, „Бельскі гостінэць", 3/2000, no. 8-9. Published on the http://kamunikat.fontel.net website [accessed on 22.03.2016].

53 During the strong gale in the January of 1869 the tombstone of Krzysztof Brun was severly damaged. The tree growing on the side fell over and destroyed the cross crowning the tombstone. The restoration of damage was entrusted to Józef Mantzel. „Kurier Warszawski”, 1869, no. 12, p. 4.

54 See: information pertaining to the tombstone of Andrzej Wołowski.
} 
simply the creator of the ornamental pedestal ${ }^{55}$. My research indicates that the remaining parts of the tombstone were not original works of Antoni Messing, either. This type of late Baroque-style pedestals decorated with regency ornamentation was used in the second and third decades of the eighteenth century as a base for e.g. free-standing monumental religious sculptures. The images of Immaculate Mary, the Holy Trinity and St. John Nepomucene popularised by the counter-Reformation movement became particularly widely spread in the Habsburg Monarchy. In Poland the most numerous examples can be found in the Lower Silesia region, formerly under the reign of Habsburgs ${ }^{56}$. Today the pedestals most closely resembling the Warsaw statue adorn the plazas in Otmuchów (the statue of Victorious Mother of God - 1734), Dobromierz (the statue of St. John Nepomucene - 1728) and the bridge leading to the abbey of Cisterians in Lubiąż (the statues of Blessed Virgin Mary and St. John Nepomucene - 1723) $)^{57}$. Particularly the pedestals in Dobromierz and Lubiąż display major similarities to the first group of tombstones patterned directly after the pedestal of the statue located in front of the Observant Fathers Church in Warsaw. The ornamentation of the pedestals is only missing dual garlands spread between volutes. However, I doubt Messing used them as models for his own work. There are no premises which could confirm this sculptor's connection to the Silesia region. It is more probable that he drew inspiration from a different work located until the outbreak of World War II in Wilanów near Warsaw.

In the beginning of the Fifties of the nineteenth century, on the upper garden platform, $v i s$ - $\grave{a}$-vis the corner pavilions of the main palace complex, two stone Neobaroque vases were $\operatorname{set}^{58}$. They were the works of an Italian architect Enrico Marconi who came to Poland in 1822 and since the Twenties of the nineteenth century had been living and working in Warsaw ${ }^{59}$. He was connected with the Potockis family since the middle of the Thirties. In the years 1834-1838 for them he prepared plans for modernising the landscape surrounding the palace in Natolin and designed the Neogothic mausoleum for Aleksandra and Stanisław Potocki in Wilanów ${ }^{60}$. Marconi returned to work dedicated to the Wilanów residence in 1845 where he supervised overhaul of the palace, initially in cooperation with Francis Maria Lanci and Bolesław Podszczański and later independently, during which he introduced a number of alterations in the interiors, the closest surroundings and in the terrain in front of the palace ${ }^{61}$.

\footnotetext{
55 The researcher discovered confirmation in press information. „Kurier Warszawski”, 1854, no. 179, p. 949; M.I. Kwiatkowska, Rzeźbiarze..., p. 44.

56 See: K. Kalinowski, Rzeźba barokowa na Śląsku, Warszawa 1986.

57 K. Kalinowski, Lubiąż, Wrocław-Warszawa-Kraków 1970, pp. 164-165; K. Kalinowski, Rzeźba..., p. 57, pp. 275-276.

58 The vases can be seen on, for instance, xylographies in "Tygodnik Ilustrowany [Weekly Illustrated]" based on the drawings of Podbielski and the drawings of Dymitrowicz from the book written by Hipolit Skimbrowicz and Wojciech Gerson. „Tygodnik Ilustrowany”, 7/ 1863, no. 192, p. 209; H. Skimborowicz, W. Gerson, Wilanów. Album widoków i pamiątek, Warszawa 1877, p. 73.

59 S. Łoza, Op. Cit., p. 188; S. Łoza, Henryk Marconi i jego rodzina, Warszawa 1954, pp. 8-17.

60 In Natolin Marconi built a propyleum beside the annex, erected a Mauritanian style bridge and gate as well as a Doric temple and an aqueduct. The listed buildings were erected in years 1834-1838. In 1834 the architect prepared the design for the mausoleum of the Potockis and since 1836 he had been supervising its construction. S. Lorentz, Natolin, Warszawa 1948, pp. 273-275; W. Fijałkowski, Mauzoleum Potockich $w$ Wilanowie, ,Spotkania z Zabytkami”, 2011, no. 3-4, pp. 38-41.

${ }_{61}$ The following installations were erected according to designs of Enrico Marconi in the years 1845-1870: the gate in Morysin with gatekeeper's accommodation, the hospital and the house of a doctor near the residence in Wilanów, the fence surrounding the cemetery in Wilanów, interiors of the Grand Hallway, the palace chapel, the
} 

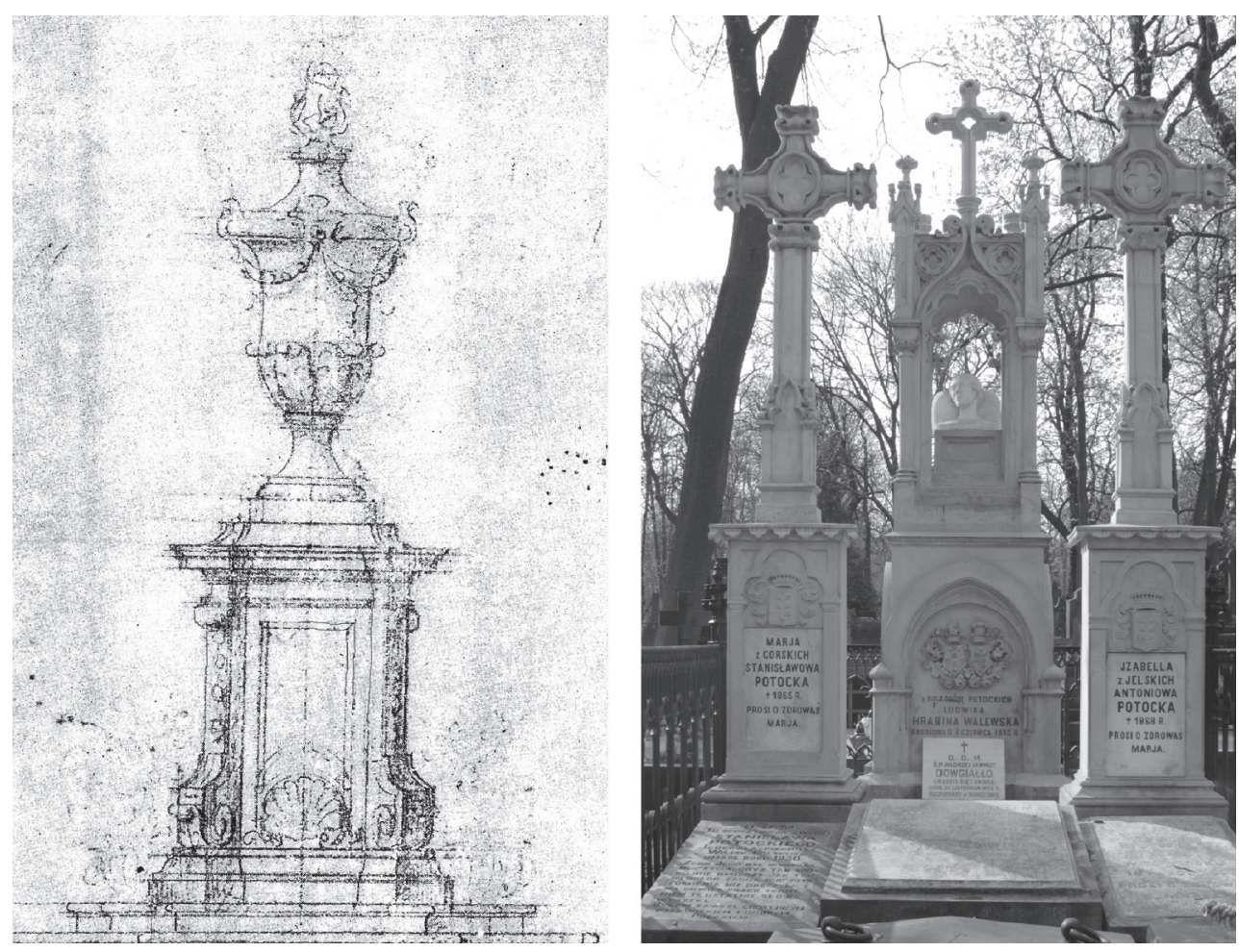

The design of the Garden Vase for the Wilanów park, the drawing by E. Marconi - approx. 1850. Reproduction by: M. Dubrowska, Rzemiosło..., Warszawa 1987, p. 38 and the tomb of Stanisław and Antoni Potocki in Powązki cemetery in Warsaw, approx. 1845-1851. Photo by M. Wiraszka

During this period of modernisation of the Potockis' residence two garden vases were made. The design plans, kept in The Central Archives of Historical Records in Warsaw, are dated approx. 1850 [pic. 5]. The descriptive text in the Italian language located below the drawing Con piedi di Minter a bronzo; da Galleria con piedi di zinko bronzati suggests that the vases were supposed to be cast in Minter's factory from pewter and covered with bronze ${ }^{62}$. Archival pictures and photographs confirm that the original design was not realised ${ }^{63}$. Instead of being cast from metal, the vases and the pedestals were sculpted from stone.

The form of vases' bases designed by Marconi most closely resembles the form of the pedestals from the second group of tombstones, which is characterised by limited ornamentation. In turn, the details adorning the vases: the leaves of acanthus covering the bottom part of the chalice and the garlands attached to the rim of the cover, imitate the embellishments of the pedestals from the first group modelled directly after the statue

\footnotetext{
pump station building in the park and the church of St. Anna. J. Cydzik, W. Fijałkowski, Wilanów-dzieje, architektura, konserwacja, Warszawa 1989, p. 21, pp. 37-41, pp. 93-95, pp. 103-106, p. 112.

62 Katalog rysunków architektonicznych Henryka i Leandra Marconich w Archiwum Głównym Akt Dawnych w Warszawie, compiled by T.S. Jaroszewski i A. Rottermund, Warszawa 1977, p. 105.

63 See: J. Cydzik, W. Fijałkowski, Op. Cit., p. 41.
} 
located in the front of St. Anthony Church at Senatorska Street. Thus it can be conjectured that Messing knew the Wilanów rendition.

The tombstones of the Messings and the Potockis families also share the form of the cross crowning the pedestal. Its form is similar to coping of the tombstones of Stanisław and Antoni Potocki, which are located in Powązki cemetery (plot no. 25, row 1-2, approx. 1844-1845 $)^{64}$. The pair of crosses set on rectangular pedestals flanks the Neogothic aedicula with a bust of a woman set in the middle. The profile of the arms of the crosses (quadrangular cross-section with a pair of cylinders merged along the entire length of edges) and their ends (leaves of acanthus) are similar to the construct used by Messing in the second group of the tombstones ${ }^{65}$. Pedestals of those monuments, devoid of sculpted ornamentation, have simpler crosses. Instead of medallions with the head of Man of Sorrows or Madonna at the intersection of beams, they have rosettes set on an oval field. These examples differ in the ornamentation of the base of the cross. The tombstones made by Messing are adorned with acanthus whereas the tombstones of the Potockis are decorated with simple Neogothic forms which can be also observed in the centre of the cross in the form of quatrefoils inscribed into a circle. Since the tombstones made for the Potockis were created earlier as they could have served as an inspiration for Messing ${ }^{66}$.

In the light of the factographic and formal ascertainment performed, it is impossible to determine the contribution of Messing to creation of the design of the statue intended for the Observant Fathers Church in Warsaw. It is known with complete certainty that Messing was not the author of the statue of Madonna. However, he most certainly was the creator of the pedestal. This fact is confirmed by the signature of the sculptor located on the side of the pedestal. The design of the base of the statue was created on the basis of a slightly modified design of the garden vases made by Marconi and ordered by August Potocki to be placed in Wilanów. The time of creation of both renditions is very similar (approx. 1850 and 1851). However, there is no precise date for the creation of Marconi's designs or the creation of the stone garden vases made on the basis of his design, which were presumably made in one of Warsaw masonry workshops. On the other hand, it is hard to imagine that Marconi would imitate Messing's idea. It is more likely that the sculptor created the pedestal according to Marconi's design or that he slightly modified and used architect's design when he was cooperating with the architect during creation of the vases for Wilanów. In such a case it would be a case similar to the one related with the authorship of the statue of Madonna, commonly attributed to Messing by the Warsaw press, which was, in reality, a work of Kaufmann $^{67}$.

\footnotetext{
${ }^{64}$ The tomb in Powązki cemetery serves as the resting place of e.g.: Stanisław Potocki (1776-1830), a general of infantry, his daughter Ludwika Walewska née Potocka (1814-1844) and his brother, Antoni Potocki (1780-1850), a general and a senator. K.W. Wóycicki, Cmentarz Powazkowski pod Warszawa, vol. 2, Warszawa 1856, p. 72-73; S. Szenic, Cmentarz Powazkowski 1790-1850. Zmarli i ich rodziny, vol. 1, Warszawa 1979, pp. 234-235, pp. 420421.

65 The first cross of this type crowned the tombstone of Aleksander Lepigé in 1854.

${ }^{66}$ The tombstones of the Potockis family were raised in Powązki cemetery probably in the years 1845-1851, either after the death of Ludwika Walewska née Potocka or the death of Antoni Potocki. A lithography depicting the tombstones of the Potockis was included in the work of Kazimierz W. Wójcicki. K.W. Wóycicki, Op. Cit., pp. 228-229 (pictures and graphics by W. Walkiewicz).

67 „Kurier Warszawski”, 1851, no. 326, pp. 1739; F.M. Sobieszczański, Kościót..., p. 365.
} 
The preserved works and the information collected by Maria I. Kwiatkowska and Aleksandra Melbechowska-Luty ${ }^{68}$ indicate that Messing was proficient with architectural and decorative forms whereas he entrusted portraits and figures which caused him some "trouble" in relation to other, more talented, artists. Thus the three statues of Madonna were created by sculptors: Ludwik Kaufmann and Tadeusz Czajkowski and the medallion on the tombstone of Teofil Lesiński was created by Władysław Oleszczyński ${ }^{69}$. Therefore the owner of the Powązkowska 6 workshop was more of a stonecutter-craftsman rather than a sculptor-artist. For the majority of his works was created on the basis of other people's designs or was ordered by other creators. Thus in the light of the collected information and facts combining the elements imitating the Neobaroque form of the pedestal from Wilanów with the Neogothic cross crowning the tombstone of the Potockis family in Powązi cemetery and their modification could be the sole artistic contribution of this sculptor.

Thus Messing's contribution did not consist of creating an original design but the skillful use of the publicity accompanying the creation of the statue of Blessed Virgin Mary on the day of its reveal on the 7th of December 1851 and, primarily, when then statue was illuminated towards the end of July $1853^{70}$. In the same year the first two tombstones were erected in Powązki cemetery: the tombstone of Andrzej Wołowski (after the 15th of August) and of Elżbieta Colin (7th of December). In the workshop at the address: 6 Powązkowska Street the remaining 17 orders were completed in the years 1854-1874. Apart from the tombstone of Ludwik Bogumił Reineke the remaining tombstones were made during the period of Antoni Messing's ownership.

\section{Antoni Messing- co-creator of the Blessed Virgin Mary's statue located in front of the Reformed Church and co-author of series of tombstones patterned after it and raised at the cemeteries of Warsaw Summary}

Antoni Messing (ca. 1821-1867) the owner of the stone workshop located in Warsaw on 6 Powązkowska Street (mtge. 27C) is currently most famous for one monument- the Statue of the Virgin Mary of Immaculate Conception which was placed in front of the Church of St Antony of Padua on Senatorska Street (1851). What made this monument different from other independently standing monuments was the use of lanterns which at evening time illuminated the statue of the Virgin (1853). The innovative idea spread not only around Warsaw, but also outside the city boundaries.

\footnotetext{
68 See: M.I. Kwiatkowska, A. Melbechowska-Luty, Op. Cit., p. 495.

69 The statue to the design by Wojciech Bobiński was finished in 1862. At that time, on the 14th of November, a mass was celebrated and the remains were transferred to the family grave. The medallion depicting the bust of Teofil Lesiński was finished in the latter half of 1863. „Kurier Warszawski”, 1862, no. 261, p. 1483; „Kurier Warszawski”, 1864, no. 31, p. 190; M.I. Kwiatkowska, Rzeźbiarze..., p. 75.

70 At times of the tragedy befalling Warsaw, crowds of the faithful gathered around the statue to pray. Every year, throughout the entire month of May, during evening hours the Litany of Mother or God was sung in front of the statue. The image of the statue was widely known owing to numerous xylographies and lithographed copies published in illustrated magazines and calendars. These reproductions most frequently depict the statue in the evening hours when view is the most spectacular. „Kurier Warszawski”, 1854, no. 179, p. 949; Pomniki święte..., p. 61, p. 62 ; „Kurier Warszawski”, 1857, no. 119, p. 629; F.M. Sobieszczański, Kościół ..., p. 364; Statua Matki Boskiej..., p. 52 .
} 
References to the monument elevated by Messing were not limited to the way and form of illuminating the statue. The inventory research conducted on Warsaw cemeteries enable the extraction of a group of tombstones imitating the shape and the decor of the plinth of the statue of the Virgin. The number of examples of this collection of tombstones numbers 19. Their execution dates back to the period 1853-1874 - with one exception only, all of them were elevated during the period of Antoni Messing's ownership of the stone workshop. All of them represent the same commemoration in the form of a crucifix located on a plinth. Examples can be separated into two groups. One, comprising 8 tombstones, the closest to the original, the other, comprising 11 examples preserves the architectural structure without the sculptural decor. The origin of the formal concept is to be traced in the project of Henryk Marconi's garden vase designed for Wilanowski Park (ca. 1845-1851) as well as the finishing elements of the Stanisław and Antoni Potocki's tombstones. Consequently, the contribution of Messing consists in the creation of the series of tombstones modelled on the statue of the Virgin Mary rather than the originality of the project.

Keywords: Warsaw, The Palace of Wilanów, The Powązkowski Cemetery, The Evangelical Augsburg Cemetery, The Evangelical Reformed Cemetery, The Orthodox Cemetery in Wola, Henryk Marconi, Antoni Lessing, the statue of the Virgin Mary of the Immaculate Conception

About the author: Marta Wiraszka Ph.D, a lecturer at the Art History Institute of the Cardinal Stefan Wyszyński University in Warsaw. She works on the topics of history of urban planning and architecture of the first half of the nineteenth century and the first half of the twentieth century, in particular in the areas of former south-east peripheries of the Republic of Poland as well as chapels and mausoleums erected in Polish Christian creed cemeteries. 